\title{
The effect of nutritional backgrounds on the formation of leaf surface and yield and green mass of corn
}

\author{
Marina Yu. Mikhailova* and Ivan P. Talanov \\ Kazan State Agrarian University, 420015 Kazan, Russia
}

\begin{abstract}
The leading branch of agriculture in Tatarstan is animal husbandry. In animal husbandry, the main direction is the production of milk and cattle meat. In the diet of dairy cows, corn is an integral component. The share of fodder corn in the total cultivated areas is on average 30-35\%. A limiting factor in the cultivation of corn is the lack of macronutrients in the soil. To obtain stable high yields of green mass of corn, it is necessary to choose the right combination of NPK, based on soil indicators. In this regard, it is necessary to improve the mineral nutrition systems of highly productive adaptive maize hybrids. The effect of fertilizers on leaf surface growth and photosynthetic potential in maize crops was studied in the field on gray forest soils of the Volga region of the Republic of Tatarstan. A significant increase in the yield of green mass was found due to the increased level of mineral nutrition of plants. The fertilizer provided an increase in leaf area by $2.6-9.82$ thousand $\mathrm{m}^{2} / \mathrm{ha}$ on the option $\mathrm{N}_{60} \mathrm{P}_{54} \mathrm{~K}_{168}$ and $4.85-14.56$ thousand $\mathrm{m}^{2} / \mathrm{ha}$ in $\mathrm{N}_{180} \mathrm{P}_{154} \mathrm{~K}_{294}$. The maximum value of this indicator was obtained from the Newton hybrid for the interphase period of flowering-milk ripeness on fertilized variants was between 9.79 and 10.23 thousand $\mathrm{m}^{2} / \mathrm{ha}$, against 7.07 thousand $\mathrm{m}^{2} /$ ha on the control variant. The photosynthetic potential was the highest hybrids (1924.91 and 1956.91 thousand $\mathrm{m}^{2} \mathrm{x}$ day/ha for the option of $\mathrm{N}_{60} \mathrm{P}_{54} \mathrm{~K}_{168}$ and 2039.84 and 2066.31 thousand $\mathrm{m}^{2} \mathrm{x}$ day/ha for the $\mathrm{N}_{180} \mathrm{P}_{154} \mathrm{~K}_{294}$ ). Consequently, the planned yields of green mass were obtained on crops of hybrids Flint-200 and Newton 42,9 and 43.9 t/ha with the introduction of calculated doses of mineral fertilizers at $50 \mathrm{t} / \mathrm{ha}$ and 62.6 and $65.3 \mathrm{t} / \mathrm{ha}$ against the background of mineral fertilizers at $70 \mathrm{t} / \mathrm{ha}$. Based on the calculations of economic efficiency, it follows that the cultivation of the Newton hybrid against the background of making NPK at the highest cost (28151.5 RUB/ha) and the lowest cost of 1 ton of green mass of corn (431.1 RUB) provides a greater net income (11028.5 RUB/ha) with the best level of profitability $(39.2 \%)$.
\end{abstract}

\section{Introduction}

Corn - is very responsive to photoactive radiation, which contributes to the intensive accumulation of biologically active substances. However, it should be noted that the culture of corn in a broad sense, along with this feature, is also responsive to soil and climatic conditions, where optimal nutritional parameters play a crucial role in obtaining high productivity $[1,2]$.

Experiments with the use of mineral fertilizers in corn crops are carried out not only in the regions of the Russian Federation [3-5], but also on other continents [6, 7].

Along with the biological features of corn hybrids and weather conditions, according to Sidelnikova N.A. and Smirnova V.V., plant density and mineral fertilizers had a smaller impact on the leaf surface area [5].

On the leached chernozem of the Stavropol Upland, fertilizer doses of the brand $\mathrm{N}_{17} \mathrm{P}_{17} \mathrm{~K}_{17}$, regardless of the method of fertilizer, increased the area of the leaf surface of corn for silage [8].

In the conditions of the Volga region of the Republic of Tatarstan, the largest increase in the leaf surface occurred in the crops of the Flint hybrid - 200 [9].
Comparing the data on the effect of mineral nutrition on the indicators of chlorophyll activity and corn productivity, the level of increase in corn yield resulting from application of fertilizers was significantly higher than the level of increase in photosynthetic activity of chlorophyll. There was a noticeable increase in corn productivity. The collection of its dry matter increased by $43 \%$, and the yield of green mass - by $24 \%$. The yield increase occurs as a result of the redistribution of photosynthesis products in favor of the above-ground mass [10].

The complex use of macro-fertilizers in background of as a supplement to liming and pre-sowing treatment of seeds with zinc-containing compounds increased the coefficient of productivity of photosynthesis to $2.03 \%$, from $0.56 \%$ in tropical Africa [11].

The use of high-efficiency fertilizers, such as urea with a polymer coating, can be a good option for managing nitrogen to increase the yield of corn, improve grain quality and reduce nitrogen in the soil [12].

In North Dakota, a positive response of corn yield to potash fertilizer application $\left(\mathrm{K}_{130}\right.$ and $\left.\mathrm{K}_{200}\right)$ was revealed at 25 sites [13].

\footnotetext{
* Corresponding author: Marisha.m.u@ mail.ru
} 


\section{Research methods}

Studies were carried out in 2013-2015 in field experiments on crops of adaptive corn hybrids: Krasnodar - 194, Flint - 200, Koenigs, ROSS - 140 and Newton (in the tables, numbering will be used: № 1 Krasnodar - 194, № 2 - Flint - 200, № 3 - Koenigs, № 4 - ROSS - 140 and № 5 - Newton). The soil is gray forest with a low humus content of $2.1 \%$, high content of mobile phosphorus $151 \mathrm{mg} / \mathrm{kg} \mathrm{P}_{2} \mathrm{O}_{5}$ and potassium $172 \mathrm{mg} / \mathrm{kg} \mathrm{K} \mathrm{K}_{2} \mathrm{O}$.

Mineral fertilizers were applied in two ways:

- preseeding - diammofoska $(10: 26: 26)+$ potassium salt (0: 0: 60);

- dressing with interrow processing - ammonium nitrate (34: 0: 0).

Macroelements were calculated by calculation and balance method, taking into account soil fertility for the planned yield of green mass $50\left(\mathrm{~N}_{60} \mathrm{P}_{54} \mathrm{~K}_{168}\right)$ and $70 \mathrm{t} / \mathrm{ha}$ $\left(\mathrm{N}_{180} \mathrm{P}_{154} \mathrm{~K}_{294}\right)$. The repetition is threefold.

Samples of plants were collected in phases of 7-8 leaves, flowering and milky ripeness of corn grain. Leaf surface area was calculated by die cutting. The photosynthetic potential (AF) and its productivity were calculated by the method of Nichiporovich. The net productivity of photosynthesis (PPF) was determined by the increase in the dry mass of plants, attributed to the leaf surface area during the reference period [14].

\section{Results}

The most important indicator of the formation of a crop of green mass of corn is the leaf area. The average amount of mineral fertilizers in the flowering phase over three years ensured an increase in leaf area by $2.6-9.82$ thousand $\mathrm{m}^{2} /$ ha in the variant with introduction of NPK at $50 \mathrm{t} / \mathrm{ha} \mathrm{N}_{60} \mathrm{P}_{54} \mathrm{~K}_{168}$ and (70 t/ha) 4.85-14.56 thousand $\mathrm{m}^{2} /$ ha in $\mathrm{N}_{180} \mathrm{P}_{154} \mathrm{~K}_{294}$ (Table 1).

The greatest responsiveness to improved nutrition was revealed in Koenigs and ROSS-140 hybrids. In the phase of milk maturity, the leaf surface area on the fertilizer application in the calculation of $50 \mathrm{t} / \mathrm{ha}$ of green mass was 47.59 thousand $\mathrm{m}^{2} / \mathrm{ha}$ and 38.37 thousand $\mathrm{m}^{2} / \mathrm{ha}$, respectively. In one version - the planned production of $70 \mathrm{t} / \mathrm{ha}$ of green mass of corn, the leaf area of the Koenigs hybrid was 48.38 thousand $\mathrm{m}^{2} / \mathrm{ha}$, and in the ROSS-140 hybrid - 42.92 thousand $\mathrm{m}^{2} / \mathrm{ha}$. Less responsiveness to the reception of intensification was revealed in the Flint - 200 hybrid.

The trend of positive responsiveness of corn hybrids to the application of mineral fertilizers has been preserved in terms of the increase in leaf surface during the interphase periods of culture development.

The growth of the Newton hybrid leaf surface for the interphase flowering period - milky ripeness on the 50 and $70 \mathrm{t} / \mathrm{ha}$ mineral fertilizer application options amounted to 9.79 and 10.23 thousand $\mathrm{m}^{2} /$ ha. Without fertilization, the growth of the leaf surface during the period of intensive growth of corn by hybrids was:
Krasnodar - 194-18.75 thousand $\mathrm{m}^{2} / \mathrm{ha}$, Flint 200-26.01 thousand $\mathrm{m}^{2} /$ ha, Koenigs -25.24 thousand $\mathrm{m}^{2}$ /ha, ROSS - 140-13.08 thousand $\mathrm{m}^{2} / \mathrm{ha}$, Newton 23.89 thousand $\mathrm{m}^{2} / \mathrm{ha}$. The values of this indicator against the background with the introduction of mineral fertilizers at $50 \mathrm{t} / \mathrm{ha}$ were higher on average by 5.5 and against the background of the application of NPC at $70 \mathrm{t} / \mathrm{ha}$ it was 6.1 thousand $\mathrm{m}^{2} / \mathrm{ha}$.

Table 1. The area of the leaf surface and its increase in interfacial periods of corn development, thousand $\mathrm{m}^{2} / \mathrm{ha}$

\begin{tabular}{|c|c|c|c|c|c|c|c|}
\hline \multirow[b]{2}{*}{ 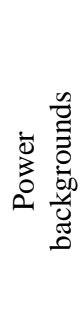 } & \multirow[b]{2}{*}{$\begin{array}{l}\stackrel{0}{0} \\
\stackrel{0}{0}\end{array}$} & \multicolumn{3}{|c|}{ Leaf area } & \multicolumn{3}{|c|}{ Leaf surface growth } \\
\hline & & 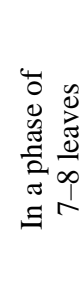 & 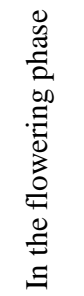 & 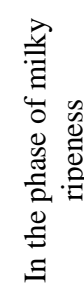 & 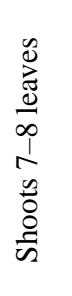 & 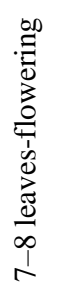 & 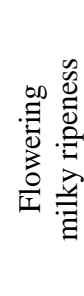 \\
\hline \multirow{5}{*}{ 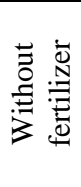 } & 1 & 6.05 & 24.80 & 30.68 & - & 18.75 & 5.88 \\
\hline & 2 & 5.99 & 32.00 & 39.91 & - & 26.01 & 7.90 \\
\hline & 3 & 6.37 & 31.61 & 37.00 & - & 25.24 & 5.39 \\
\hline & 4 & 6.51 & 19.58 & 27.36 & - & 13.08 & 7.78 \\
\hline & 5 & 7.65 & 31.53 & 38.60 & - & 23.89 & 7.07 \\
\hline \multirow{5}{*}{ 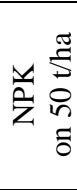 } & 1 & 7.68 & 33.60 & 38.57 & 1.63 & 25.92 & 4.97 \\
\hline & 2 & 8.07 & 37.21 & 42.58 & 2.08 & 29.14 & 5.37 \\
\hline & 3 & 7.65 & 37.92 & 47.59 & 1.27 & 30.27 & 9.67 \\
\hline & 4 & 5.94 & 29.40 & 38.37 & 0.57 & 23.46 & 8.97 \\
\hline & 5 & 9.34 & 35.15 & 44.94 & 1.70 & 25.80 & 9.79 \\
\hline \multirow{5}{*}{ 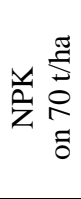 } & 1 & 9.48 & 34.71 & 40.99 & 3.43 & 25.23 & 6.28 \\
\hline & 2 & 8.62 & 39.33 & 45.54 & 2.63 & 30.71 & 6.21 \\
\hline & 3 & 9.41 & 39.68 & 48.38 & 3.04 & 30.27 & 8.70 \\
\hline & 4 & 8.43 & 34.14 & 42.92 & 1.92 & 25.71 & 8.78 \\
\hline & 5 & 10.68 & 36.38 & 46.61 & 3.03 & 25.70 & 10.23 \\
\hline & \multicolumn{7}{|l|}{ LSD } \\
\hline & $05 \mathrm{~A}$ & 0.08 & 0.04 & 0.06 & & & \\
\hline & B & 0.07 & 0.04 & 0.09 & & & \\
\hline & $\mathrm{AB}$ & 2.76 & 6.34 & 7.24 & & & \\
\hline
\end{tabular}

There is a direct relationship between the photosynthetic activity of the leaves and the accumulation of dry matter by plants, which subsequently affects the increase in yield (Table 2).

The number of "working days" of the leaf surface during vegetation on a windy background was the limit from 1125.95 to 1695.99 thousand $\mathrm{m}^{2} \mathrm{x}$ day/ha. The maximum and minimum values of this indicator against the background of application of mineral fertilizers at $50 \mathrm{t} /$ ha 1956.52 thousand $\mathrm{m}^{2} \mathrm{x}$ day/ha in the hybrid Koenigs and $70 \mathrm{t} / \mathrm{ha} 1538.58$ thousand $\mathrm{m}^{2} \mathrm{x}$ day/ha in the hybrid ROSS-140. Option in the variant with introduction of mineral fertilizers at $70 \mathrm{t} / \mathrm{ha}$, the photosynthetic potential was the limit of 1766.96 to 2066.31 thousand $\mathrm{m}^{2} \mathrm{x}$ day/ha the maximum values in hybrids Koenigs and Flint - 200.

The introduction of macronutrients increased both the leaf surface area and the indicator of the photosynthetic potential of corn leaves. 
Table 2. Photosynthetic potential of corn in milky-wax ripeness, thousand $\mathrm{m}^{2} \mathrm{x}$ day/ha and net photosynthesis productivity, $\mathrm{g} / \mathrm{m}^{2}$

\begin{tabular}{|c|c|c|c|c|c|c|c|c|c|}
\hline \multirow{4}{*}{$\begin{array}{c}\begin{array}{c}\text { Power } \\
\text { backgrounds }\end{array} \\
\text { Without } \\
\text { fertilizers }\end{array}$} & \multirow{3}{*}{$\begin{array}{c}\text { Hybrids } \\
1\end{array}$} & \multicolumn{8}{|c|}{ Interphase periods } \\
\hline & & \multicolumn{2}{|c|}{ Seedlings $-7-8$ leaves } & \multicolumn{2}{|c|}{ 7-8 leaves-flowering } & \multicolumn{2}{|c|}{ flowering milky ripeness } & \multicolumn{2}{|c|}{ Total } \\
\hline & & 96.80 & 0.72 & 462.75 & 1.02 & 776.72 & 1.04 & 1336.27 & 2.78 \\
\hline & 2 & 95.84 & 0.83 & 569.85 & 1.12 & 970.79 & 0.66 & 1636.48 & 2.62 \\
\hline & 3 & 95.55 & 0.84 & 588.69 & 0.80 & 960.54 & 0.67 & 1644.78 & 2.30 \\
\hline & 4 & 100.91 & 0.79 & 391.35 & 1.46 & 633.69 & 0.87 & 1125.95 & 3.12 \\
\hline & 5 & 122.35 & 0.82 & 626.88 & 0.93 & 946.76 & 0.93 & 1695.99 & 2.67 \\
\hline \multirow{5}{*}{$\begin{array}{c}\text { NPK on } 50 \\
\text { t/ha }\end{array}$} & 1 & 119.04 & 0.67 & 577.92 & 2.18 & 1010.38 & 1.15 & 1707.34 & 4.00 \\
\hline & 2 & 133.16 & 0.90 & 633.92 & 2.21 & 1157.83 & 0.97 & 1924.91 & 4.08 \\
\hline & 3 & 118.58 & 0.76 & 683.55 & 1.57 & 1154.39 & 0.80 & 1956.52 & 3.12 \\
\hline & 4 & 95.04 & 0.84 & 494.76 & 1.98 & 948.78 & 0.99 & 1538.58 & 3.81 \\
\hline & 5 & 154.11 & 0.65 & 711.84 & 1.83 & 1041.17 & 1.27 & 1907.12 & 3.74 \\
\hline \multirow{5}{*}{$\begin{array}{c}\text { NPK on } 70 \\
\text { t/ha }\end{array}$} & 1 & 151.68 & 0.66 & 618.66 & 2.68 & 1059.80 & 2.04 & 1830.14 & 5.38 \\
\hline & 2 & 137.92 & 0.87 & 671.30 & 2.71 & 1230.62 & 1.77 & 2039.84 & 5.35 \\
\hline & 3 & 141.15 & 0.85 & 736.35 & 2.51 & 1188.81 & 1.51 & 2066.31 & 4.88 \\
\hline & 4 & 130.67 & 0.77 & 595.98 & 2.85 & 1040.31 & 1.50 & 1766.96 & 5.12 \\
\hline & 5 & 170.88 & 0.76 & 752.96 & 2.43 & 1037.38 & 1.89 & 1961.22 & 5.08 \\
\hline & LSD 05 & 0.49 & 0.03 & 0.54 & 0.02 & 0.81 & 0.03 & & \\
\hline & B & 0.97 & 0.02 & 0.59 & 0.04 & 0.79 & 0.04 & & \\
\hline & $\mathrm{AB}$ & 16.29 & 0.10 & 36.19 & 0.25 & 102.64 & 0.18 & & \\
\hline
\end{tabular}

The introduction of macronutrients increased both the leaf surface area and the indicator of the photosynthetic potential of corn leaves.

During the growing season, the maximum values of the net productivity of photosynthesis of corn among fertilized varieties were in hybrids Krasnodar - 194 and Flint -200 or 4.00 and $4.08 \mathrm{~g} / \mathrm{m}^{2}$ when planning production of $50 \mathrm{t} / \mathrm{ha}$ of green mass, 5.38 and $5.35 \mathrm{~g} / \mathrm{m}^{2}$ when making $\mathrm{N}_{180} \mathrm{P}_{154} \mathrm{~K}_{294}$.

On an unsuitable background, the net productivity of photosynthesis for hybrids was: Krasnodar - 194 was $2.78 \mathrm{~g} / \mathrm{m}^{2}$, Flint - 200-2.62 g/m², Koenigs - $2.30 \mathrm{~g} / \mathrm{m}^{2}$, ROSS - $140-3.12 \mathrm{~g} / \mathrm{m}^{2}$, Newton $-2.67 \mathrm{~g} / \mathrm{m}^{2}$.

Table 3. The yield of corn hybrids in the phase of milky-wax ripeness, $\mathrm{t} / \mathrm{ha}$

\begin{tabular}{|c|c|c|c|c|c|c|}
\hline \multirow{3}{*}{$\begin{array}{c}\text { Power } \\
\text { backgrounds }\end{array}$} & \multirow{3}{*}{ Hybrids } & \multicolumn{4}{|c|}{ Productivity, t/ha } & \multirow{3}{*}{ 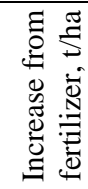 } \\
\hline & & \multicolumn{3}{|c|}{ Years } & \multirow[b]{2}{*}{ 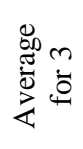 } & \\
\hline & & 2013 & 2014 & 2015 & & \\
\hline \multirow{5}{*}{ 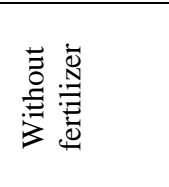 } & 1 & 27.7 & 28.4 & 19.3 & 25.1 & - \\
\hline & 2 & 26.5 & 27.5 & 18.6 & 24.2 & - \\
\hline & 3 & 23.1 & 31.6 & 14.1 & 22.9 & - \\
\hline & 4 & 19.4 & 26.5 & 21.9 & 22.6 & - \\
\hline & 5 & 28.3 & 32.5 & 23.4 & 28.1 & - \\
\hline \multirow{5}{*}{ 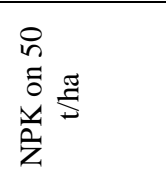 } & 1 & 42.3 & 44.8 & 36.7 & 41.3 & 16.1 \\
\hline & 2 & 43.3 & 45.5 & 40.0 & 42.9 & 18.7 \\
\hline & 3 & 30.3 & 42.3 & 33.4 & 35.3 & 12.4 \\
\hline & 4 & 33.7 & 44.6 & 35.1 & 37.8 & 15.2 \\
\hline & 5 & 43.9 & 45.2 & 42.6 & 43.9 & 15.8 \\
\hline \multirow{5}{*}{$\begin{array}{l}\frac{P}{\pi} \\
\tilde{0} \\
\frac{a}{5} \\
\frac{\Delta}{2} \\
z\end{array}$} & 1 & 50.9 & 66.1 & 65.3 & 60.8 & 35.6 \\
\hline & 2 & 52.6 & 67.9 & 67.2 & 62.6 & 38.4 \\
\hline & 3 & 50.7 & 63.0 & 63.9 & 59.2 & 36.3 \\
\hline & 4 & 48.3 & 60.4 & 62.0 & 56.9 & 34.3 \\
\hline & 5 & 64.4 & 65.0 & 66.5 & 65.3 & 37.2 \\
\hline & $\begin{array}{c}\text { LSD } \\
05 \mathrm{~A}\end{array}$ & 0.23 & 0.23 & \multicolumn{3}{|l|}{0.23} \\
\hline & B & 0.18 & 0.26 & \multicolumn{3}{|l|}{0.26} \\
\hline & $\mathrm{AB}$ & 6.00 & 4.01 & \multicolumn{3}{|l|}{4.01} \\
\hline
\end{tabular}

The application of mineral fertilizers provided the planned high yields (Table 3). Without fertilizers on average over 3 years, the yield on hybrids was: Krasnodar - 194-25.1 t/ha, Flint - $200-24.2$ t/ha, Koenigs - 22.9 t/ha, ROSS - $140-22.6$ t/ha, Newton $28.1 \mathrm{t} / \mathrm{ha}$.

Against the background with in the variant with introduction of NRK at 50 and $70 \mathrm{t} / \mathrm{ha}$, high yield of green mass was obtained from Flint hybrids - 200 (42.9 and $62.6 \mathrm{t} / \mathrm{ha}$ ) and Newton (43.9 and $65.3 \mathrm{t} / \mathrm{ha}$ ).

The lowest yield on the same background was obtained when the Koenigs hybrid was sown at $35.3 \mathrm{t} / \mathrm{ha}$ $\left(\mathrm{N}_{60} \mathrm{P}_{54} \mathrm{~K}_{168}\right)$ and ROSS - $140-56.9 \mathrm{t} / \mathrm{ha}\left(\mathrm{N}_{180} \mathrm{P}_{154} \mathrm{~K}_{294}\right)$.

For applying NPK at $50 \mathrm{t} / \mathrm{ha}$, the yield increase by hybrids was a limit of 12.4 to $18.7 \mathrm{t} /$ ha with a maximum value for the Flint hybrid - 200 and a minimum value for the Koenigs hybrid.

When NPK was applied at $70 \mathrm{t} / \mathrm{ha}\left(\mathrm{N}_{180} \mathrm{P}_{154} \mathrm{~K}_{294}\right)$, the increase in yield of green mass in the cultivation of the Krasnodar hybrid - 194 was 35.6 t/ha; hybrid ROSS $140-34.3 \mathrm{t} / \mathrm{ha}$ and in hybrid Newton $-37.2 \mathrm{t} / \mathrm{ha}$.

Improving the nutrient regime of the soil in the cultivation of maize for green mass by applying mineral fertilizers was economically beneficial (Table 4).

On the variant without fertilization the main indicators that characterize the economic effect were the hybrid within the following limits: the value of the crop from 13560 to 16860 RUB for 1 ton, the costs of 11515.0 to $13499.9 \mathrm{RUB} / \mathrm{ha}$, the cost of 1 ton of green mass from 480.4-502.9 rubles, net income from 2225.0 to $3360.1 \mathrm{RUB} / \mathrm{ha}$, profitability level from 19.3 to $24.8 \%$.

A greater economic effect on this option was obtained during the cultivation of the Newton hybrid. In the NPK variant, the economic efficiency indicators increased by almost half by $50 \mathrm{t} / \mathrm{ha}$ and $70 \mathrm{t} / \mathrm{ha}$. When you make $\mathrm{N}_{60} \mathrm{P}_{54} \mathrm{~K}_{168} 50$ t/ha less the cost of the resulting product was a hybrid Newton - 437.5 RUB for $1 \mathrm{t}$, which is 37.2 RUB more profitable cultivation of hybrid Koenigs (cost 474.7 RUB). Also on the option of 
obtaining 50 t/ha of green mass, the hybrid Flint 200 had good indicators of economic efficiency. Net income amounted to $6735.6 \mathrm{RUB} / \mathrm{ha}$ at the level of profitability of $35.4 \%$. This trend continued at the option of any $\mathrm{N}_{180} \mathrm{P}_{154} \mathrm{~K}_{294} 70 \mathrm{t} / \mathrm{ha}$.

Despite the fact that production costs have increased significantly due to high yields net income from 1 ha was the hybrid Krasnodar - $194-9410.9$ RUB./ha, the hybrid Flint - 200 - 9915.6 RUB/ha, the hybrid Koenigs - 8519.4 RUB/ha, the hybrid ROSS - 140 - 8062.1 RUB/ha and the maximum of the hybrid Newton 11028.5 RUB/ha. The level of profitability was the highest in the hybrids Flint - and 200 Newton (35.9 and $39.2 \%$ ). That is 0.5 and $15.4 \%$ more than the option with the introduction of calculated doses of fertilizers to yield $50 \mathrm{t} / \mathrm{ha}$ and 2.1 and $14.4 \%$ of the option without mineral fertilizers.

Table 4. Economic efficiency of corn cultivation for green mass

\begin{tabular}{|c|c|c|c|c|c|c|}
\hline $\begin{array}{c}\text { Power } \\
\text { backgrounds }\end{array}$ & 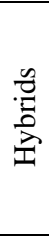 & 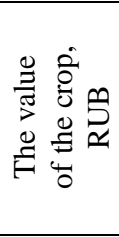 & 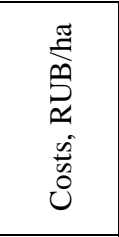 & 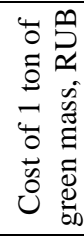 & 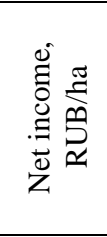 & 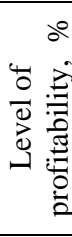 \\
\hline \multirow{5}{*}{$\begin{array}{l}\text { Without } \\
\text { fertilizer }\end{array}$} & 1 & 15060.0 & 12167.6 & 484.8 & 2892.4 & 23.7 \\
\hline & 2 & 14520.0 & 12047.0 & 497.8 & 2473.0 & 20.5 \\
\hline & 3 & 13740.0 & 11515.0 & 502.9 & 2225.0 & 19.3 \\
\hline & 4 & 13560.0 & 11183.1 & 494.8 & 2376.9 & 21.3 \\
\hline & 5 & 16860.0 & 13499.9 & 480.4 & 3360.1 & 24.8 \\
\hline \multirow{5}{*}{$\begin{array}{l}\text { NPK on } \\
50 \mathrm{t} / \mathrm{ha}\end{array}$} & 1 & 24780.0 & 18343.7 & 444.2 & 6436.3 & 35.1 \\
\hline & 2 & 25740.0 & 19004.4 & 442.9 & 6735.6 & 35.4 \\
\hline & 3 & 21180.0 & 16755.9 & 474.7 & 4424.1 & 26.4 \\
\hline & 4 & 22680.0 & 17666.9 & 467.4 & 5013.1 & 28.4 \\
\hline & 5 & 26340.0 & 19207.3 & 437.5 & 7132.7 & 37.1 \\
\hline \multirow{5}{*}{$\begin{array}{l}\text { NPK on } \\
70 \mathrm{t} / \mathrm{ha}\end{array}$} & 1 & 36480.0 & 27069.1 & 445.2 & 9410.9 & 34.8 \\
\hline & 2 & 37560.0 & 27644.4 & 441.6 & 9915.6 & 35.9 \\
\hline & 3 & 35520.0 & 27000.6 & 456.1 & 8519.4 & 31.5 \\
\hline & 4 & 34140.0 & 26077.9 & 458.3 & 8062.1 & 30.9 \\
\hline & 5 & 39180.0 & 28151.5 & 431.1 & 11028.5 & 39.2 \\
\hline
\end{tabular}

Note: the price of 1 ton of corn in the phase of milk-wax ripeness $=600 \mathrm{RUB} / \mathrm{t}$

\section{Conclusion}

The application of mineral fertilizers at 50 and $70 \mathrm{t} / \mathrm{ha}$ in the cultivation of corn for green mass provided an increase in the leaf surface area by 11.01 and 15.56 thousand $\mathrm{m}^{2} / \mathrm{ha}$, compared to the background without fertilizers.

The photosynthetic potential was maximum for the Flint hybrids - 200 and Koenigs (1924.91 and 1956.91 thousand $\mathrm{m}^{2} \mathrm{x}$ day/ha) on the NPK introduction variant at $50 \mathrm{t} / \mathrm{ha} \quad\left(\mathrm{N}_{60} \mathrm{P}_{54} \mathrm{~K}_{168}\right)$ and against the introduction of NPK at 70 t/ha $\left(\mathrm{N}_{180} \mathrm{P}_{154} \mathrm{~K}_{294}\right) 2039.84$ and 2066.31 thousand $\mathrm{m}^{2} \mathrm{x}$ day/ha.

Planned green mass yields were obtained from the Flint-200 and Newton hybrids 42.9 and 43.9 t/ha against the introduction of NPK for $50 \mathrm{t} /$ ha to 62.6 and $65.3 \mathrm{t} / \mathrm{ha}$ against the application of mineral fertilizers for $70 \mathrm{t} / \mathrm{ha}$.

Based on the calculations of economic efficiency, it follows that the cultivation of the Newton hybrid against the background of making NPK at the highest cost (28151.5 RUB/ha), and the lowest cost of 1 ton of green mass of corn (431.1 RUB), provides the highest net income (11028.5 RUB/ha) with the best level of profitability $(39.2 \%)$.

\section{References}

1. S.E. Alikberova, A.T. Gaziev, Dependence of photosynthetic activity and adaptation of maize culture on nutritional conditions, New and nontradit. plants and prosp. for their use, 13, 225-228 (2018)

2. I.P. Talanov, M.Y. Mikhailova, L.Z. Karimova, Responsiveness of maize hybrids to the introduction of calculated doses of mineral fertilizers in the conditions of the Pre-Volga region of the Republic of Tajikistan, Bull. of Kazan State Agrar. Univer., 2(36), 123-127 (2015)

3. S.A. Semina, I.V. Gavryushina, A.S. Paliychuk, K.E. Denisov, N.P. Molchanova, Influence of fertilizers and standing density on the grain yield of maize in the forest-steppe zone of the Volga region, Agrar. Sci. J., 3, 25-29 (2017)

4. V.I. Nikitishen, L.M. Terekhova, V.I. Lichko, The formation of the assimilation apparatus and the productivity of photosynthesis of plants in different conditions of mineral nutrition, Agrochem., 8, 35-43 (2007)

5. N.A. Sidelnikova, V.V. Smirnova, Formation of biometric indicators of corn hybrids in various growing conditions, Innovat. in the AIC: probl. and prosp., 4 (20), 144-152 (2018)

6. M.J. Arruda Coelho, D. Ruiz Diaz, G.M. Hettiarachchi, F. Dubou Hansel, P.S. Pavinato, Soil phosphorus fractions and legacy in a cornsoybean rotation on Mollisols in Kansas, USA, Geoderma Regional, 18, e00228 (2019)

7. R.B.A. Rafael, M.L. Fernandez-Marcos, S. Cocco, M.L. Ruello, F. Fornasier, G. Corti, Benefits of Biochars and NPK Fertilizers for Soil Quality and Growth of Cowpea, Vignaunguiculata L. Walp. in an Acid Arenosol, Pedosphere, 29(3), 311-333 (2019)

8. S.A. Korostylev, A.N. Esaulko, M.S. Sigida, E.V. Golosnoy, N.V. Gromova, I.O. Lysenko, Responsiveness of corn for silage on modern fertilizers on leached chernozem of the Stavropol Upland, Modern probl. of sci. and ed., 6, 1639 (2014)

9. M.Y. Mikhailova, I.P. Talanov, The nutritional value of corn hybrids in the cultivation of green mass, Agrar. Sci., 4(16), 9-11 (2016)

10. S.K. Mingalev, A.Yu. Ovsyannikov, Y.A. Ovsyannikov, I.V. Surin, The influence of mineral nutrition on the indicators of the photosynthetic activity of corn chlorophyll, Agrar. Bull. of the Urals, 10(128), 25-27 (2016) 
11. E.V. Mamonov, Photosynthetic activity of maize in tropical conditions, depending on the mineral nutrition, News of TSCA 3, 74-79 (2005)

12. A.K. Sutradhar, D.B. Arnall, B.L. Dunn, W.R. Raun, Does phosphite, a reduced form of phosphate contriute to phosphorus nutrition in corn (Zea mays L.), J. of Plant Nutrit., 42(9), 982-989 (2019)
13. J.S. Breer, T. DeSutter, M.K. Raar, A. Chatterjee, L. Sharma, D. Franzen, Potassium reuirements for corn in North Daota: Influence of clay mineralogy, Soil Sci. Society of Amer. J., 83(2), 429-436 (2019)

14. E.A. Kalinina, Influence of biologically active compounds on the growth, photosynthesis and productivity of maize, News of TSCA, 3, 181-186 (2009) 